\title{
Reliability and validation of Turkish version of the Dallas Pain Questionnaire
}

\author{
Dallas Ağrı Anketi'nin Türkçe versiyonunun güvenilirliği ve geçerliliği
}

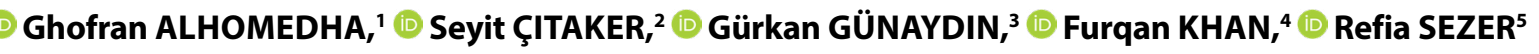

\begin{abstract}
Summary
Objectives: Evaluation of low back pain (LBP) requires a condition specific disability questionnaire along with pain and satisfaction measure such as self-assessment pain scales. Dallas Pain Questionnaire (DPQ) is a 16-item visual analog scale, developed for evaluating patient's cognitions about the percentage that chronic pain affects four aspects of the subject's lives. It's easy to understand; can be answered in 3-5 $\mathrm{min}$ and can be scored in $<1 \mathrm{~min}$. This reliability and validation study offers health-care providers an opportunity to utilize this distinct questionnaire in Turkish population with back pain. The objectives are translation of Dallas questionnaire from English to Turkish language and to perform validation and reliability study.

Methods: A total of 102 patients ( 79 women and 23 men) with mean age of 50.2 years and LBP for at least 3 months answered DPQ along with five other previously translated and validated questionnaires in Turkish language. Fifty-nine of these patients participated retest reliability after 7 days. Internal consistency and test-retest analyzes were conducted to determine the reliability and convergent validity was evaluated for the validation study.

Results: The questionnaire was noted to have high internal consistency. The test-retest analysis revealed an excellent correlation (ICC=0.969). Pearson correlation coefficient shows that all subscales (sections) of DPQ are significant and comparable with each of the other questionnaires included in this study proving that it has sufficient convergent validity $(p<0.001)$.
\end{abstract}

Conclusion: The Turkish version of DPQ is content, valid, and reliable. DPQ is sensitive to use in patients with LBP.

Keywords: Dallas Pain Questionnaire; low back pain; reliability; Turkish version; validity.

\section{Özet}

Amaç: Bel ağrısının değerlendirilmesi, öz değerlendirme ölçekleri gibi ağrı ve memnuniyet ölçümü ile birlikte duruma özel bir sakatlık anketi gerektirir. Dallas Ağrı Anketi, hastanın, yaşamında dört yönün kronik ağrıdan etkilendiği yüzdeye ilişkin bilişlerini değerlendirmek için geliştirilmiş 16 maddelik bir görsel analog skaladır. Anlaması kolaydır; 3-5 dakikada tamamlanabilir ve 1 dakikadan daha kısa sürede puanlanabilir. Bu güvenilirlik ve geçerlilik çalışması, sağlık çalışanlarına, sırt ağrısı olan Türk popülasyonda bu farklı anketi kullanma fırsatı sunmaktadır. Çalışmanın amacı, Dallas Anketi'nin İngilizce'den Türkçe'ye çevrilmesi ve geçerlik ve güvenirlik çalışması yapılmasıdır.

Gereç ve Yöntem: Ortalama yaşı 50,2 yıl olan ve en az 3 aydır bel ağrısı olan 102 hasta (79 kadın ve 23 erkek), Dallas Ağrı Anketi'ni ve daha önce Türkçe'ye çevrilmiş ve onaylanmış diğer beş anketi yanıtladı. Bu hastaların $59^{\prime}$ u 7 gün sonra tekrar test güvenilirliğine katıldı. Güvenilirliği belirlemek için iç tutarılık ve test-tekrar test analizleri yapılmış ve geçerlilik çalışması için yakınsak geçerlilik değerlendirilmiştir.

Bulgular: Anketin iç tutarlılığının yüksek olduğu görülmüştür. Test-tekrar test analizi mükemmel bir korelasyon ortaya koymuştur (ICC=0,969). Pearson korelasyon katsayısı, Dallas Ağıı Anketi'nin tüm alt ölçeklerinin (bölümlerinin) anlamlı olduğunu ve bu çalışmaya dahil edilen diğer anketlerin her biri ile karşılaştırılabilir olduğunu göstermektedir ve yeterli yakınsak geçerliliğe sahip olduğunu kanıtlamaktadır ( $p<0.001$ ).

Sonuç: Dallas Ağrı Anketi'nin Türkçe versiyonu kapsamlı, geçerli ve güvenilirdir. Dallas Ağrı Anketi, bel ağrısı olan hastalarda kullanıma duyarlıdır.

Anahtar sözcükler: Dallas Ağrı Anketi; bel ağrısı; güvenilirlik; Türkçe versiyon; geçerlilik.

\footnotetext{
'Department of Physical Therapy and Rehabilitation, Gazi University Institute of Health Science, Ankara, Turkey ${ }^{2}$ Department of Physical Therapy and Rehabilitation, Gazi University Faculty of Health Science, Ankara, Turkey ${ }^{3}$ Department of Physical Therapy and Rehabilitation, Aydın Adnan Menderes University Faculty of Health Sciences, Ankara, Turkey ${ }^{4}$ Department of Orthopedic Surgery, Tehran University of Medical Sciences, Tehran, Iran ${ }^{5}$ Department of Physical Therapy and Rehabilitation, İzzet Baysal Training and Research Hospital, Bolu, Turkey
}

Submitted (Başvuru tarihi) 14.10.2020 Accepted after revision (Düzeltme sonrası kabul tarihi) 27.01.2021 Available online date (Online yayımlanma tarihi) 05.11.2021

Correspondence: Dr. Furqan Khan. Department of Orthopedic Surgery, Tehran University of Medical Sciences, Tehran, Iran.

Phone: +98 - 9036150465 e-mail: drfurqan@outlook.com

(c) 2022 Turkish Society of Algology 


\section{Introduction}

The evaluation of low back pain (LBP) requires consideration of a number of variables. For complete evaluation, a condition-specific disability questionnaire along with pain and satisfaction measure should be used. ${ }^{[1]}$ Self-reporting pain scales are a common method for evaluating patient outcome in back pain. ${ }^{[2]}$ In developed countries, LBP is the most common type of pain in adults and most common musculoskeletal complaint for visiting a physician. ${ }^{[3]}$ It has huge socioeconomic impact, including most number of missed work days. ${ }^{[4]}$

There are several condition-specific questionnaires of back pain in current use that has demonstrated good reliability and validity in an appropriate population: (1) The Oswestry Low Back Disability Index (ODI) developed from experimental questionnaires designed for individuals receiving physical therapy ${ }^{[5]}$ (2) The Low Back Outcome Score (LBOS), which emphasizes objective questions with the aim of giving a broadly based status for low back illness. ${ }^{[6]}$ (3) The Roland Morris Disability Questionnaire (RMDQ) derived from the Sickness Impact Profile by selection of items thought to be relevant to patients with back pain. ${ }^{[7]}$ (4) The Bournemouth questionnaire (BQ), based on the dimensions of the International Classification of Functioning and Disability, it also takes the cognitive aspects of LBP in consideration. ${ }^{[8]}$ (5) Quebec Back Pain Disability Scale (QBDS) constructed using a conceptual approach to disability assessment and empirical methods of item development and analysis. ${ }^{[9]}$

The Dallas Pain Questionnaire (DPQ) was developed by Lawlis, Cuencas, Selby, and McCoy. ${ }^{[10]}$ DPQ is 16-item visual analog scale (VAS) for evaluating subject's perception about the percentage that chronic pain affects four aspects of patient's life: (1) Daily activities such as intensity of pain, personal care, lifting, walking, sitting, standing, and sleeping. (2) Work and leisure activities including social life, traveling, and vocational affairs. (3) Anxiety, depression, and (4) social interest such as interpersonal relationship, social support, and punishing responses. ${ }^{[10]}$ Some of the advantages of DPQ are it is easy to understand, time efficient assessment, can be answered in 3-5 min, and it can be scored in $<1 \min ^{.10,11]}$
The objectives of this study were to translate DPQ from English to Turkish language, to validate the questionnaire, and to check its reliability in Turkish population with LBP. DPQ has been previously translated and validated in French language. ${ }^{[1]}$

\section{Material and Methods}

\section{The Questionnaire}

DPQ has 16 items divided into four sections according to the aspects of patients lives; each item is rated by patient on a VAS from $0 \%$ corresponding to "no pain" or "not at all" to $100 \%$ corresponding to "all the time." Each component is further divided into 5-8 segments with each one given a value between 0 and 7, 0 to first segment on left side, 1 to next segment, and so on till 7. All the question scores in each section are summed and multiplied by a constant specific for that section, total of first section (daily activities) is multiplied by 3 , the rest of section totals are multiplied by 5 .

\section{Translation and Cultural Adaptation}

Permission was obtained from the original developers of DPQ before commencing this study. The translation and cultural adaptation proceedings were conducted in different stages using the forward-backward model based on epidemiological guidelines; (1) translation, (2) back-translation, (3) committee review, (4) pre-testing, and (5) weighting of scores. ${ }^{[12]}$ Two native Turkish speakers individually translated original DPQ to the Turkish language. One of these translators was physical therapist with good knowledge of English language, who was aware of the study to provide accurate conceptual meaning in the Turkish language. The other translator was professional multilingual translator and English literature expert who was unaware of the study concept and provided the literal meaning of questions. Two separate translators then merged these two Turkish versions into a single questionnaire. It was then back-translated to English by two independent professional translators (one native English speaker with good knowledge of Turkish and the other vice versa), both were unaware of the study.

The expert committee comprising the physiotherapist, English and Turkish literature experts, and two bilingual translators reviewed the resul- 
tant translation and back-translation. The pre-final form of the questionnaire was constructed and evaluated in a pilot study group of 50 participants ( 25 patients with LBP and 25 healthy individuals), with a clarity form to provide a better understanding of each question (face validity). The expert committee reviewed the evaluation and submissions of the pilot group and then created the final questionnaire (Appendix 1).

\section{Patients}

Ethics commission approval was obtained before commencing the study. One hundred and thirtytwo patients participated in this study. All patients had a complaint of LBP for at least 3 months. Pregnant women and patients with spinal tumor, infection, fracture, and/or history of spine surgery were excluded from this study. Thirty patients who did not complete the survey or answered incorrectly were as well excluded. Informed consent (written) was obtained from all the patients. Participants had to answer the developed Turkish version of the DPQ questionnaire along with a demographics form and previously validated and translated Turkish versions of RMDQ, ODI, QBDS, BQ, and short form-36 (SF-36). Moreover, 59 patients answered the DPQ questionnaire after 7 days for the test-retest reliability.

\section{Statistical Analyses}

The Statistical Package for the Social Sciences, Windows 21.0 package program was used for all statistical analyzes. Analyzes are expressed as mean \pm standard deviation and percentages. Internal consistency and test-retest analyzes were conducted to determine the reliability of the DPQ. Internal consistency analysis was calculated with Cronbach alpha and test-retest results with intraclass correlation coefficient (ICC). Cronbach alpha and ICC values of 0.80 and above were considered significant. ${ }^{[13,14]}$ The validity of DPQ was evaluated by convergent validity. Convergent validity was calculated by correlating the subscales of the DPQ and the total scores of the RMDQ, ODI, QBDS, and the subparameters of the SF-36. Pearson's correlation coefficient was used for this analysis and it was interpreted as $0.81-1.00$ excellent, $0.61-0.80$ very good, 0.41-0.60 good, 0.21-0.40 weak, and 0-0.20 no correlation. ${ }^{[15]}$ All values were considered significant at $\mathrm{p}<0.05$.
Table 1. Demographics of the patients $(n=102)$

\begin{tabular}{|c|c|c|}
\hline & $\mathbf{n}$ & $\%$ \\
\hline \multicolumn{3}{|l|}{ Sex } \\
\hline Men & 23 & 22.5 \\
\hline Women & 79 & 77.5 \\
\hline Age (year) & \multicolumn{2}{|c|}{$50.23 \pm 15.78$} \\
\hline Height (cm) & \multicolumn{2}{|c|}{$165.28 \pm 9.46$} \\
\hline Weight (kg) & \multicolumn{2}{|c|}{$74.86 \pm 17.00$} \\
\hline BMI (mean) & \multicolumn{2}{|c|}{$27.4 \mathrm{~kg} / \mathrm{m}^{2}$} \\
\hline $\begin{array}{l}\text { Back pain duration } \\
\text { (month) (mean } \pm S D)\end{array}$ & \multicolumn{2}{|c|}{$90.13 \pm 94.34$} \\
\hline \multicolumn{3}{|l|}{ Education } \\
\hline Primary & 44 & 43.1 \\
\hline High school & 4 & 3.9 \\
\hline University & 54 & 52.9 \\
\hline \multicolumn{3}{|l|}{ Employment } \\
\hline Working & 47 & 46.0 \\
\hline Unemployed & 42 & 41.1 \\
\hline Retired & 13 & 12.7 \\
\hline \multicolumn{3}{|l|}{ Marital status } \\
\hline Married & 68 & 66.6 \\
\hline Single & 34 & 33.3 \\
\hline Smoking & 31 & 30.3 \\
\hline
\end{tabular}

BMI: Body mass index; SD: Standard deviation.

Table 2. Cronbach Alpha values of DPQ

\begin{tabular}{lc}
\hline Subscales of the Dallas & Cronbach Alpha \\
\hline Daily activities & 0.892 \\
Work/leisure activities & 0.906 \\
Anxiety/depression & 0.817 \\
Social interest & 0.904 \\
Total (mean) & $\mathbf{0 . 8 7 8}$ \\
\hline
\end{tabular}

DPQ: Dallas Pain Questionnaire.

\section{Results}

Overall, 102 patients participated in this study. Mean age was 50.23 years, 79 women and 23 men. Median LBP duration was 90.13 months. Test-retest reliability analysis was conducted 1 week later, with 59 patients who had participated previously. Table 1 demonstrates the demographic data. The Cronbach alpha values for internal consistency were studied for each section of the questionnaire (Table 2). Its value for entire survey was recorded as 0.878 . ICC for the retest reliability of the questionnaire was re- 
Table 3. Test-retest analyses of DPQ

\begin{tabular}{lcc}
\hline DPQ (n=59) & ICC (95\% Cl) & $\begin{array}{c}\text { Upper-lower } \\
\text { bound }\end{array}$ \\
\hline Question 1 & 0.952 & $0.919-0.971$ \\
Question 2 & 0.968 & $0.947-0.981$ \\
Question 3 & 0.957 & $0.927-0.974$ \\
Question 4 & 0.973 & $0.955-0.984$ \\
Question 5 & 0.978 & $0.963-0.987$ \\
Question 6 & 0.907 & $0.844-0.945$ \\
Question 7 & 0.965 & $0.941-0.979$ \\
Daily activities & $\mathbf{0 . 9 7 2}$ & $\mathbf{0 . 9 5 3 - 0 . 9 8 3}$ \\
Question 8 & 0.974 & $0.957-0.985$ \\
Question 9 & 0.938 & $0.895-0.963$ \\
Question 10 & 0.951 & $0.918-0.971$ \\
Work/leisure activities & $\mathbf{0 . 9 7 6}$ & $\mathbf{0 . 9 5 9 - 0 . 9 8 6}$ \\
Question 11 & 0.940 & $0.899-0.964$ \\
Question 12 & 0.945 & $0.908-0.967$ \\
Question 13 & 0.975 & $0.957-0.985$ \\
Anxiety/depression & $\mathbf{0 . 9 5 2}$ & $\mathbf{0 . 9 1 9 - 0 . 9 7 1}$ \\
Question 14 & 0.977 & $0.962-0.987$ \\
Question 15 & 0.978 & $0.964-0.987$ \\
Question 16 & 0.977 & $0.961-0.986$ \\
Social interest & $\mathbf{0 . 9 7 7}$ & $\mathbf{0 . 9 6 0 - 0 . 9 8 7}$ \\
Total & $\mathbf{0 . 9 6 9}$ & $\mathbf{0 . 9 1 9 - 0 . 9 8 7}$ \\
\hline
\end{tabular}

DPQ: Dallas Pain Questionnaire; ICC: Interclass Correlation Coefficient; $\mathrm{Cl}$ : Confidence interval. corded as $0.972,0.976,0.952$, and 0.977 for each of four sections of DPQ (Table 3). Significant Cronbach alpha and ICC indicate good internal consistency and retest reliability of $D P Q$.

Validity of DPQ was studied separately for each of its sections by correlating with the total scores of the RMDQ, ODI, QBDS, and the subparameters of the SF-36 (Table 4). Pearson's correlation coefficient showed that all subscales (sections) of DPQ are significant and comparable with each of the abovementioned questionnaires and all parameter of SF-36 (Table 4). This proves that DPQ has sufficient convergent validity $(p<0.001)$.

\section{Discussion}

There are at least 22 pain scales reported in literature and no survey has proven superiority of one questionnaire over the other. ${ }^{[16]}$ There is no gold standard subjective patient measurement scale. Some authors argue that pain alone is a narrow definition of patient outcome and correlates poorly with function. ${ }^{[2]}$ However, pain a persistent problem and is a key indicator of physical impairment; it is associated with depression and decreased physical/SF and quality of life. Therefore, assessment of pain cannot be overlooked in specific conditions.

Table 4. Validity of DPQ

\begin{tabular}{|c|c|c|c|c|}
\hline & \multicolumn{4}{|c|}{ Pearson's correlation of the subscales of Dallas } \\
\hline & Daily activities & Work/leisure activities & Anxiety/depression & Social interest \\
\hline $\mathrm{BQ}$ & $0.776^{*}$ & $0.789 *$ & $0.823^{*}$ & $0.779 *$ \\
\hline RMDQ & $0.827^{*}$ & $0.818^{*}$ & $0.776^{*}$ & $0.798^{*}$ \\
\hline QBDS & $0.847^{*}$ & $0.797^{*}$ & $0.776^{*}$ & $0.777^{*}$ \\
\hline ODI & $0.857^{*}$ & $0.829^{*}$ & $0.818^{*}$ & $0.819^{*}$ \\
\hline \multicolumn{5}{|l|}{ SF-36 } \\
\hline $\mathrm{PF}$ & $-0.808^{*}$ & $-0.777^{*}$ & $-0.751^{*}$ & $-0.759^{*}$ \\
\hline $\mathrm{RL}$ & $-0.756^{*}$ & $-0.756^{*}$ & $-0.781^{*}$ & $-0.761^{*}$ \\
\hline $\mathrm{BP}$ & $-0.787^{*}$ & $-0.795^{*}$ & $-0.816^{*}$ & $-0.769^{*}$ \\
\hline SF & $-0.696^{*}$ & $-0.736^{*}$ & $-0.803^{*}$ & $-0.759^{*}$ \\
\hline $\mathrm{GMH}$ & $-0.454^{*}$ & $-0.500^{*}$ & $-0.573^{*}$ & $-0.495^{*}$ \\
\hline RLE & $-0.552^{*}$ & $-0.583^{*}$ & $-0.711^{*}$ & $-0.694^{*}$ \\
\hline VT & $-0.522^{*}$ & $-0.572^{*}$ & $-0.574^{*}$ & $-0.551^{*}$ \\
\hline GHP & $-0.400^{*}$ & $-0.475^{*}$ & $-0.389 *$ & $-0.430^{*}$ \\
\hline
\end{tabular}

BQ: Bournemouth questionnaire; RMDQ: Roland Morris Disability Questionnaire; QBPDS: Quebec Back Pain Disability Scale; ODI: Oswestry disability index; SF-36: short form-36; PF: Physical function; RL: Role physical; BP: Bodily pain; SF: Social functioning; GMH: General mental health; RLE: Role emotional; VT: Vitality; GHP: General health; *:p<0.001. 
$D P Q$ is mainly designed to assess patients with LBP. It is based on a cognitive and behavioral conception of chronic LBP. It was designed to evaluate the impact of pain on everyday life. ${ }^{[10]}$ Initially, it was based on a concept of cognitive behavioral change to chronic pain that takes not only the impact of pain as perceived by the individual physically, psychologically, and socially but also measure that how patient adopts with pain. DPQ has wide exploration of social activities, interpersonal relationships, and psychological state that goes beyond the framework of physical capabilities. ${ }^{[17]}$ It not only covers effects of pain on daily living but also its effects on emotional aspects of subject's social relationships. The developers of DPQ tested the questionnaire on 104 chronic LBP patients; they reported excellent internal consistency (reliability coefficient 0.970 ). This is in comparison to our study (Cronbach alpha 0.878 and ICC 0.969).

DPQ is diverse, global measure of several aspects affecting chronic pain. It's section on daily activities covers; pain and intensity, personal care, lifting, sitting, standing, walking, and sleeping. This section of DPQ elaborates on how patients cope with pain or how much they are dependent on pain relieving substance on their day-to-day activities. The second subscale of DPQ intricate how the pain is affecting patient's work and leisure activities; social life, travelling, and vocational. The third section ornate the emotional response of pain; anxiety, emotional control, and depression. The fourth subscale of DPQ is similar to the second section, however, here, social interest of the patient is valued rather than work. This includes interpersonal relationship, social support, and punishing response.

Literature review has revealed that DPQ has been fairly used to assess the consequences of LBP. Andersen et al. ${ }^{[18]}$ used it to measure functional outcome improvement in a longitudinal study of patients undergoing spinal fusion surgery. Piperno et al. ${ }^{[19]}$ used DPQ to determine correlations between phospholipase activity, sciatica, and the impact of pain on daily life. Ozguler et al. ${ }^{[20]}$ used it to classify patients with LBP in working population. Wilhelm et al. ${ }^{[21]}$ studied sensitivity of DPQ to change and reported that it is moderately sensi- tive. DPQ has been previously translated and validated in French language; Marty et al. ${ }^{[11]}$ reported that it is reproducible, valid, and sensitive. Internal consistency validity of their study was comparable to our study (Cronbach alpha 0.89-0.91). Calmels et al. ${ }^{[17]}$ conducted a meta-analysis on LBP disability assessment tools and concluded that DPQ along with three others (RMDQ, ODI, and QBDS) among all 19 questionnaires demonstrated excellent qualities of content and construct validity, feasibility, linguistic adaptation, and international use.

Several self-assessment tools have been translated and validated in Turkish language; LBOS, BQ, ODI, RMDQ, QBPDS, and SF-36. ${ }^{[22-27]}$ However, none of these questionnaires are considered gold standard in Turkey or privileged over the other. ${ }^{[22,23]} \mathrm{As}$ DPQ is widely been used in France and with French population in Canada, ${ }^{[17]}$ we anticipate that its validation in Turkish language could offer healthcare providers in Turkey an opportunity to utilize this distinct questionnaire for patients with LBP. In our opinion, questionnaires like DPQ provide physicians with liability of practicing evidence-based medicine. The creators of DPQ recommended three predictable profiles; when sections 1 and 2 (daily and work activities) are $>50 \%$, and sections 3 and 4 (emotional and social) are $<50 \%$ then medical intervention alone would suffice for better patient outcome. When all sections are $>50 \%$, then a combination of medical and behavioral therapy may be needed. When sections $1-2$ are $<50 \%$ and subscales 3-4 are $>50 \%$, then a behavioral therapy should be considered as primary treatment. ${ }^{[10]}$

Our study proves that all sections of DPQ have good internal consistency (Cronbach alpha 0.892, $0.906,0.817$, and 0.904). The retest conducted 7 days later has shown that DPQ is reliable and sensitive tool for assessment in patient with LBP (ICC 0.969). The convergent validity Pearson's correlation has demonstrated that DPQ and all its subscales have strong correlation with all the parameters of $\mathrm{BQ}, \mathrm{RMDQ}, \mathrm{ODI}$, and QBDS (Pearson's coefficient 0.776-0.857). However, parameter of SF-36 has shown moderate correlation (coefficient $0.389-0.808$ ). This low correlation may be attributable to difference in subscales such as vitality. 


\section{Conclusion}

Turkish version of DPQ proved content and valid. It compares favorably with other established questionnaires in terms of both internal consistency and testretest reliability. Therefore, DPQ is a reliable and sensitive instrument for clinical use in patients with LBP.

\section{Conflict-of-interest issues regarding the authorship or article: None declared.}

Peer-rewiew: Externally peer-reviewed.

\section{References}

1. Müller U, Röder C, Greenough CG. Back related outcome assessment instruments. Eur Spine J 2006;15(Suppl 1):S2531. CrossRef

2. Holt $A E$, Shaw NJ, Shetty A, Greenough CG. The reliability of the low back outcome score for back pain. Spine (Phila Pa 1976) 2002;27(2):206-10. CrossRef]

3. Burns BD. An evidence-based approach to the evaluation and treatment of low back pain in the emergency department. Emerg Med Pract 2013;15(7):1-23; Quiz 23-4.

4. Luo X, Pietrobon R, Sun SX, Liu GG, Hey L. Estimates and patterns of direct health care expenditures among individuals with back pain in the United States. Spine (Phila Pa 1976) 2004;29(1):79-86. [CrossRef]

5. Fairbank JC, Couper J, Davies JB, O'Brien JP. The Oswestry low back pain disability questionnaire. Physiotherapy 1980;66(8):271-3.

6. Greenough CG, Fraser RD. Assessment of outcome in patients with low-back pain. Spine (Phila Pa 1976) 1992;17(1):36-41. [CrossRef]

7. Roland M, Morris R. A study of the natural history of back pain. Part I: Development of a reliable and sensitive measure of disability in low-back pain. Spine (Phila Pa 1976) 1983;8(2):141-4. [CrossRef]

8. Bolton JE, Breen AC. The bournemouth questionnaire: A short-form comprehensive outcome measure. I. Psychometric properties in back pain patients. J Manipulative Physiol Ther 1999;22(8):503-10. Ccrosskef

9. Kopec JA, Esdaile JM, Abrahamowicz M, Abenhaim L, Wood-Dauphinee S, Lamping DL, et al. The Quebec back pain disability scale. Measurement properties. Spine (Phila Pa 1976) 1995;20(3):341-52. [CrossRef]

10. Lawlis GF, Cuencas R, Selby D, McCoy CE. The development of the Dallas Pain Questionnaire. An assessment of the impact of spinal pain on behavior. Spine (Phila Pa 1976) 1989;14(5):511-6[ [CrossRef]

11. Marty M, Blotman F, Avouac B, Rozenberg S, Valat JP. Validation of the French version of the Dallas Pain Questionnaire in chronic low back pain patients. Rev Rhum Engl Ed 1998;65(2):126-34.

12. Guillemin F, Bombardier C, Beaton D. Cross-cultural adaptation of health-related quality of life measures: Literature review and proposed guidelines. J Clin Epidemiol
1993;46(12):1417-32. CCrossRef]

13. Weir JP. Quantifying test-retest reliability using the intraclass correlation coefficient and the SEM. J Strength Cond Res 2005;19(1):231-40. [CrossRef]

14. Schlösser TP, Stadhouder A, Schimmel JJ, Lehr AM, van der Heijden GJ, Castelein RM. Reliability and validity of the adapted dutch version of the revised scoliosis research society 22-item questionnaire. Spine J 0014;14(8):1663-1/2

15. Feise RJ, Michael Menke J. Functional rating index: A new valid and reliable instrument to measure the magnitude of clinical change in spinal conditions. Spine (Phila Pa 1976) 2001;26(1):78-86; discussion 87. [CrossRef]

16. Ruta DA, Garratt AM, Wardlaw D, Russell IT. Developing a valid and reliable measure of health outcome for patients with low back pain. Spine (Phila Pa 1976) 1994;19(17):188796. [CrossRef]

17. Calmels P, Béthoux F, Condemine A, Fayolle-Minon I. Low back pain disability assessment tools. Ann Readapt Med Phys 2005;48(6):288-97 [CrossRef]

18. Andersen T, Christensen FB, Bünger C. Evaluation of a dallas pain questionnaire classification in relation to outcome in lumbar spinal fusion. Eur Spine $2006 ; 15(11): 1671-85$.

19. Piperno M, Hellio le Graverand MP, Reboul P, Mathieu P, Tron AM, et al. Phospholipase A2 activity in herniated lumbar discs. Clinical correlations and inhibition by piroxicam. Spine (Phila Pa 1976) 1997;22(18):2061-5. [CrossRef]

20. Ozguler A, Guéguen A, Leclerc A, Landre MF, Piciotti M, Le Gall S, et al. Using the Dallas Pain Questionnaire to classify individuals with low back pain in a working population. Spine (Phila Pa 1976) 2002;27(16):1783-9. [CrossRef

21. Wilhelm F, Fayolle-Minon I, Phaner V, Le-Quang B, Rimaud $D$, Béthoux $F$, et al. Sensitivity to change of the Quebec back pain disability scale and the Dallas pain questionnaire. Ann Phys Rehabil Med 2010;53(1):15-23. [Crossketr

22. Alhomedah G, Çıtaker S, Günaydın G, Sezer R, Khan F. Reliability and validation of the Turkish version of the low back outcome score. Acta Orthop Traumatol Turc 2020;54(2):161-7,[CrossRef]

23. Gunaydin G, Citaker S, Meray J, Cobanoglu G, Gunaydin OE, Kanik ZH. Reliability, validity, and cross-cultural adaptation of the Turkish version of the Bournemouth questionnaire. Spine (Phila Pa 1976) 2016;41(21):E1292-7. CrossRef]

24. Yakut E, Düger T, Oksüz C, Yörükan S, Ureten K, Turan D, et al. Validation of the Turkish version of the Oswestry disability index for patients with low back pain. Spine (Phila Pa 1976) 2004;29(5):581-5; discussion 585, [CrossRef]

25. Küçükdeveci AA, Tennant $A$, Elhan $A H$, Niyazoglu H. Validation of the Turkish version of the Roland-Morris Disability Questionnaire for use in low back pain. Spine (Phila Pa 1976) 2001;26(24):2738-43. [CrossRef]

26. Melikoglu MA, Kocabas $H$, Sezer I, Bilgilisoy M, Tuncer T. Validation of the Turkish version of the Quebec back pain disability scale for patients with low back pain. Spine (Phila Pa 1976) 2009;34(6):E219-24 [CrossRef

27. Kocyigit $H$. Reliability and validity of the Turkish version of short form-36 (SF-36): A study in a group of patients will rheumatic diseases. Turk J Drugs Ther 1999;12:102-6. 


\section{Appendix 1}

\section{Dallas Ăgrı Anketi}

Hasta Adı Soyadı: Doğum Tarihi:

Tarih Meslek:

Lütfen okuyunuz: Bu anket ağrınızın yaşamınızı nasıl etkilediği ile ilgil olarak doktorunuza bilgi vermek amacıyla tasarlanmıştır. Cevapların size ait olduğundan emin olun. Bașkasından anketi sizin adınıza doldurmasını istemeyin. Her bölümde 0'dan 100'e kadar olan çizgi boyunca düşüncelerinizi ifade eden yere " $\mathrm{X}$ " işareti koyunuz.

Bölüm I: Ağrı ve Șiddeti

Rahatlamanız için ağrı kesici ilaç veya ağrı kesici maddelere ne derece güveniyorsunuz?

Hiç

Biraz

Her zaman

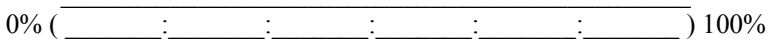

Bölüm II: Kișisel bakım

Ağrılar kişisel bakımınızı (yataktan kalkma, diş fırçalama, giyinip dışarı çıma, vs) ne derece etkiliyor?
Hiç
Biraz
Yataktan
(Ağrı yok)
kalkamıorum

$0 \%(\bar{\square}: \quad: \quad: \quad: \quad$ : $) 100 \%$

Bölüm III: Kaldırma

Birşey kaldırırken ne kadar kısıtlılık hissediyorsunuz?

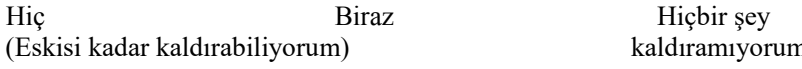

$0 \%(\div \quad: \quad: \quad: \quad: \quad: \quad$ : $\quad$ : $100 \%$

Bölüm IV: Yürüme

Yaralanma öncesi ile karşılaştırdığınızda, ağrı şu anki yürüme mesafenizi ne kadar kisitliyor?

Hiç kısıtlamıyor Çok az kısıtlıyor Az kısıtlıyor Yürüyemiyorum

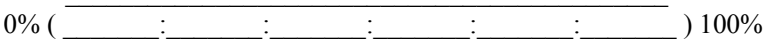

Bölüm V: Oturma

Sırt ağrısı bir sandalyede oturmanızı ne kadar kısıtlıyor?

Hiç Biraz

Hiç

(ağnı öncekiyle aynı)

oturamiyorum

$0 \%$

$100 \%$

Bölüm VI: Ayakta durma

Ağrı, uzun süre ayakta durabilme toleransınızı ne derece etkiliyor?

$\begin{array}{lrr}\text { Hiç } & \text { Biraz } & \text { Ayakta } \\ \text { eskisi gibi } & & \text { duramıorum }\end{array}$

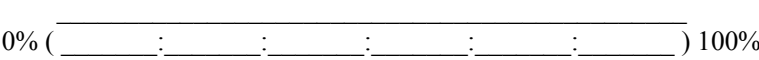

Bölüm VII: Uyku

Ağrı uykunuzu ne derece etkiliyor?

Hiç Biraz

(eskisi gibi)

Hic

uyuyamiyorum

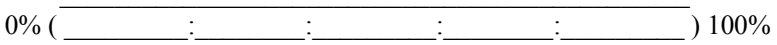

(Toplam x $3=\%$ Günlük faaliyetler üzerindeki etki)

Bölüm VIII: Sosyal yașam

Ağrı sosyal hayatınızı ne derece etkiliyor (dans etmek, oyun oynamak, dışarı çıkmak, arkadaşlarınızla yemeğe gitmek, vs)?

Hiç Biraz Hiç bir (eskisi gibi) aktivite yapamıorum $0 \%(:: \quad: \quad: \quad: \quad: \quad: \quad: \quad) 100 \%$
Bölüm IX: Seyahat etmek

Ağrı arabada yolculuk etmenizi ne derece etkiliyor?

Hiç Biraz Seyahat

(eskisi gibi) edemiyorum

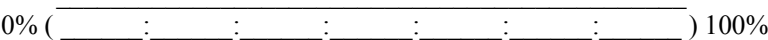

Bölüm X: Mesleki

Ağrı işinizi ne derece etkiliyor?

Hiç Biraz Çalışamıyorum

(Hiçbir etkisi yok)

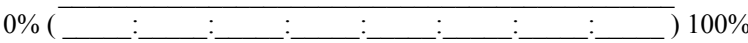

(TOPLAM x $5=\%$ Çalışma/boş zaman aktiviteleri üzerindeki etki)

Bölüm XI: Endișe /Ruh hali

Sizden istenenleri ne derece kontrol edebiliyorsunuz?

(Değişiklik yok)

Tamamen Biraz Hiç

$0 \%\left(\begin{array}{lllll}\hline: & : & : & : & :\end{array}\right) 100 \%$

Bölüm XII: Duygusal kontrol

Duygularınız üzerinde ne derece kontrolünüz olduğunu hissediyorsunuz?

Tamamen Biraz Hiç

(Değişiklik yok)

$0 \%(\div \quad: \quad: \quad: \quad: \quad: \quad: \quad: \quad) 100 \%$

Bölüm XIII: Depresyon

Ağrının başladığından bu yana ne derecede depresyon hissediyorsunuz?

Önemli ölçüde

depresyon yaşamıyorum

Depresyondan

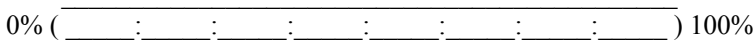

(TOPLAM x 5 =\% ___ Anksiyete / Depresyon etkisi)

Bölüm XIV: Kișilerarası ilișkiler

Ağrınızın başkalarıyla olan ilişkilerinizi ne derece değiştirdiğini düşünüyorsunuz?

Değiştirmedi Büyük ölçüde değiştirdi

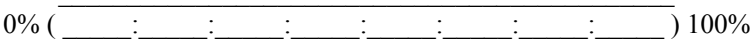

Bölüm XV: Sosyal destek

Ağrı başladığından beri başkalarından desteğe ne kadar ihtiyaç duyuyorsunuz (gündelik işleri devralmak, yemek hazırlamak vs)?

Gerek duymuyorum

Her zaman

$0 \%(\bar{\square}: \quad: \quad: \quad: \quad: \quad$ : $) 100 \%$

Bölüm XVI: Cezalandırılma tepkisi

Ağrılarınızdan dolayı başkalarının size karşı rahatsızlıklarını, hayal

kırıklıklarını veya öfkelerini ne kadar ifade ettiklerini düşünüyorsunuz?

Hiç Biraz Her zaman

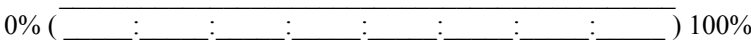

(TOPLAM x 5 =\%___ Sosyal Çıkar Engellemesi) 